\title{
An Analysis of the Optimal Design of Feed-in Tariff Policy for Photovoltaic Investments in Turkey
}

Duygu KURAL (https://orcid.org/0000-0001-7517-5807), Department of Economics, Hacettepe University, Turkey; e-mail: kuralduygu@gmail.com

Shihomi ARA (https://orcid.org/0000-0003-3424-2561), Department of Economics, Hacettepe University, Turkey; e-mail: sara@hacettepe.edu.tr

\section{Türkiye'de Fotovoltaik Yatırımlar için Tarife Garantisi Politikasının Optimal Tasarımının Bir Analizi}

\begin{abstract}
Feed-in Tariff (FIT) is the long-term agreement between governments and firms investing in solar energy, where governments guarantee to purchase the energy produced by firms. This research aims to reveal the optimal FIT design for Photovoltaic (PV) investments in Turkey. Choice Experiment based questionnaire was conducted on solar energy firms to investigate the investment preferences and monetary worth of each FIT component for investors. We found that FIT design with longer contract duration creates positive value for PV investments, while low payment amount per $\mathrm{kWh}$, tax policy for imported PV panels, and license fee decrease the attractiveness of PV investments.

Keywords

: Solar Energy, Photovoltaic Systems, Feed-In Tariff, Stated Preference, Choice Experiment, Turkey.

JEL Classification Codes : $\quad$ Q28, Q48, L98, K32, L50.

\section{$\ddot{\mathbf{O} z}$}

Tarife Garantisi (FIT), hükümetlerin firmalar tarafından üretilen enerjiyi almayı garanti ettiği, hükümetler ve güneş enerjisine yatırım yapan firmalar arasındaki uzun vadeli bir anlaşmadır. Bu araştırma, Türkiye'deki Fotovoltaik (PV) yatırımları için en uygun FIT tasarımını ortaya çıkarmayı amaçlamaktadır. Yatırımcılar için yatırım tercihlerini ve her bir FIT bileşeninin parasal değerini araştırmak üzere güneş enerjisi firmaları üzerinde Seçim Deneyi bazlı bir anket yapıldı. Daha uzun sözleşme süresi olan FIT tasarımının PV yatırımları için pozitif değer yarattığını, $\mathrm{kWh}$ başına düşük ödeme tutarı, ithal PV panelleri için vergi politikasının ve lisans ücretinin PV yatırımlarının çekiciliğini azalttığını bulduk.
\end{abstract}

Anahtar Sözcükler $\quad$ : Güneş Enerjisi, Fotovoltaik Sistemler, Tarife Garantisi, Belirtilen Tercih, Seçim Deneyi, Türkiye. 


\section{Introduction}

\subsection{Solar Energy Market and FIT in the World}

The device that generates electricity directly from the sunlight is called photovoltaic (PV) or solar cell. In recent years, investments in PV systems have increased. This trend is associated with different objectives, such as measures for climate change and $\mathrm{CO}_{2}$ emissions, sustainability and energy security. In 2019, installed PV capacity has exceeded $600 \mathrm{GW}$ in the world (See Fig.1). Two main reasons for this rise are reduced cost due to technological improvements (See Fig. 2) and increased support for PV systems.

Fig. 1

\section{Cumulative Installed PV Power [GWp]}

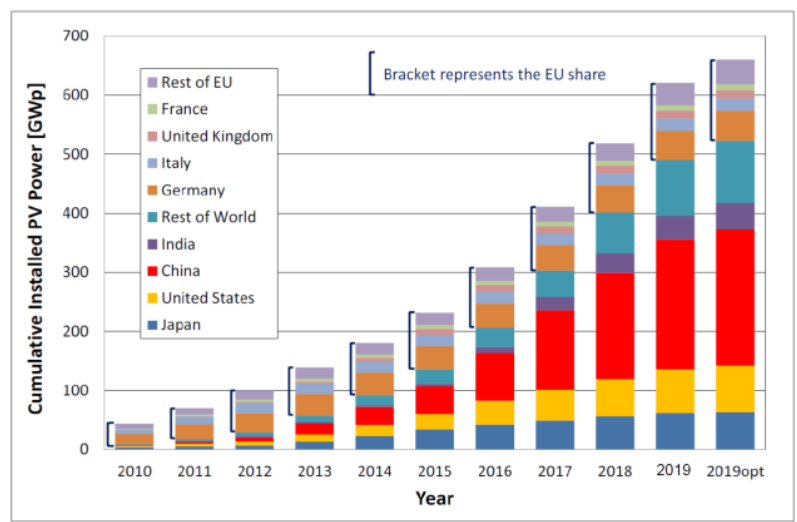

Source: European Commission, PV Status Report 2019.

Nowadays, several support mechanisms are implemented in the world in order to increase investments in renewable energy sources (RESs). One of the commonly used support mechanisms is feed-in tariff (FIT), which is a long-term purchase agreement between official authorities and firms generating electricity from RESs (Couture et al., 2010; Couture \& Cory et al., 2010; Jacobs et al., 2012; Klein et al., 2008). Governments offer longterm contracts ranging from ten to twenty-five years to producers, and governments also determine the price per kilowatt-hour (kWh) of electricity. Various studies show that FIT is the best support mechanism to enhance and extend the use of RESs. Since the long-term purchase agreement presents more stable economic conditions, it reduces investors' perceived risk, and firms choose to invest in RESs, and research and development (R\&D). Another advantage of FIT is that each country can design the FIT mechanism according to its own circumstances. Until now, various FIT designs have been used in many countries in order to increase RESs investments. In this context, there are various studies on how to design the FIT. Mendonca, Jacobs, and Sovacool (2009), Couture et al. (2010), and Klein et al. (2008) delicately addressed all the questions about how an advanced FIT design should be, from the requirements of a basic FIT design. Moreover, they showed a bad FIT design and the usual consequences. The ideal FIT design for emerging economies was examined in 
this study. Setting target, tariffs by technology and plant-size, the determination of payment duration, the presentation of certain priorities -such as priority grid access-, progress reports, and the monitoring of the policy are the basic components of the FIT mechanisms. Many countries that use the FIT design for the use of PV systems have followed these steps. Like Germany, China, and Spain, pioneering countries have amended the policy tool and FIT design several times in order to increase efficiency of the policy. Many countries that use FIT in 2016, on average, offer a 20-year payment period, use tariff differentiation, and implement tariff degression on an annual basis (Campoccia et al., 2014; Grau, 2014; Haas et al., 2010). However, Turkish Government presents a 10-year payment period for all renewables without tariff differentiation according to technology and plant-size for PV investments since 2011. Therefore, the monitoring and review of the FIT design are thought to be essential for ensuring the energy security of Turkey.

Fig. 2

\section{Solar PV Module Prices}

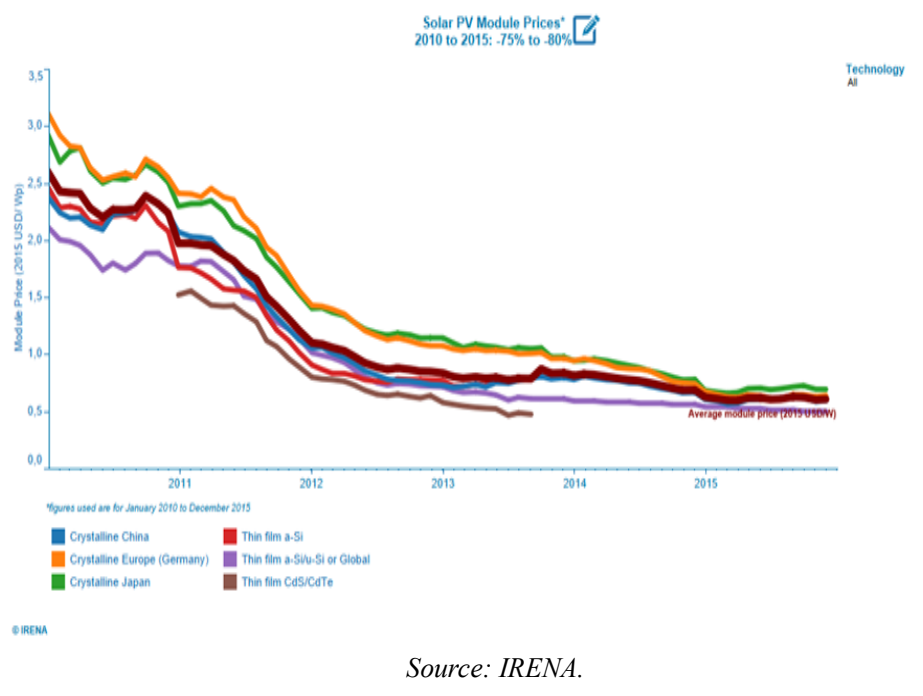

FIT design options are basically divided into two parts as Market-Independent FIT policies and Market-Dependent FIT policies. The main difference between the two concepts is whether the price offered by the authorities for generated electricity depends on the price of electricity in the market. Regardless of the changes in the price of electricity in the market, the produced electricity is offered a certain amount of FIT payment in the MarketIndependent FIT policies. Therefore, these types of policies respond better to the needs of developing RESs markets. Market-Dependent FIT policies are more suitable to increase 
competitiveness in the market; hence Market-Dependent policies are usually used in developed industries. ${ }^{1}$

In this research, three Market-Independent FIT designs were used in the questionnaire because they are more suitable for Turkey's market conditions. The first FIT design is fixed price FIT, which offers a certain payment level per kWh electricity from produced renewable energy sources, and it presents a purchase guarantee during a certain period. During this period, authorities do not take into consideration the retail price of electricity when paying the relevant amount for investors since authorities aim to improve the renewable energy market. Moreover, emerging market agents generally do not have enough power to compete with each other. This design is used by many countries to increase investments in the beginning. Since Law No.5349 was amended with Law No. 6094 in 2010, FIT design in Turkey uses a 10-year contract duration with the purchase guarantee of 13.3 USD cent/ per kWh for PV systems. The fixed price model ignores inflation and consumer price index (CPI); therefore, the revenues of the firms could decline because retail prices could exceed the FIT price. Despite this disadvantage of the fixed price model, it exhibits certainty for agents. Thanks to this certainty, they can calculate a period to compensate for their investment expenses and their total revenues. In conclusion, fixed price FIT design offers stable conditions and foreseeable revenue for investors. Another option is the fixed price model with a full or partial inflation adjustment model. In the fixed-price model with a full or partial inflation adjustment model, the value of the investment revenue is protected against inflation (Couture et al., 2010). The inflation adjustment model requires periodic regulation on FIT payment amount with respect to the inflation rate quarterly or annually. Even though the inflation adjustment model could offset the costs of a project, investors may not desire the model because of the uncertainty of total payment. The last FIT policy design option used in this study is the front-end loaded model. This model offers higher payments in the early years of FIT contract period, and then the payments begin to decline per $\mathrm{kWh}$.

\subsection{Solar energy market in Turkey}

Turkey has a rising population and economic growth; hence energy demand is increasing day by day. Because of its high population, ever-growing birthrate, and economic growth, energy security has always been a major problem for Turkey. As the country has to import an enormous share of its energy needs, its current account is affected negatively (See Fig. 3). 
Fig. 3

The Relationship between Current Account and Energy Import, 2002-2013, USDmillion

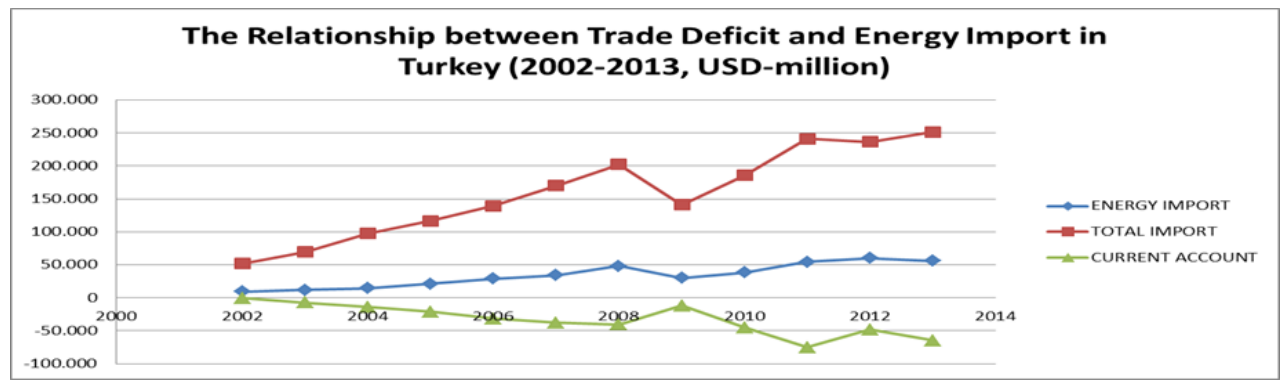

Source: Turkish Statistical Institute, Central Bank of the Republic of Turkey

However, the geographical characteristics of the country are very suitable for taking advantage of RESs. Turkey is located in between 36-42 northern latitude and 26-45 eastern longitude, having an average annual total insolation duration of 2640 hours and average annual solar radiation of $1311 \mathrm{kWh} / \mathrm{m} 2$-year. Therefore, solar energy and PV systems can be a good solution for Turkey's energy security and its sustainable economic development. Bilgen et al. (2008), Yuksel et al. (2011), Benli (2013), and Serencam et al. (2013) provide a summary of the situation of renewable energy for Turkey. They emphasize several issues such as energy utilization, energy import rate, energy supply and demand, geographical characteristic, environmental issues, emission mitigation, and air quality. According to these papers, the utilization of RESs will create positive results on Turkish economy, because energy import rate will decrease considerably, and Turkey will ensure energy security and sustainability. Moreover, investments in renewable energy fields will reduce carbon emissions, which will create livable environment for all species.

Turkish Government has followed a path in the energy field to be a member of the European Union (EU), and the government has also tried to provide energy security for about 40 years. Turkish Energy and Electricity market has undergone a liberalization and privatization process since 2001. In addition to radical changes in the energy and electricity market, Turkish Government realized a promotion need for RESs. Therefore, RES Support Mechanism was constituted by Official Authorities, and Turkish Government introduced the Law on Utilization of Renewable Energy Resources for the Purpose of Generating Electrical Energy- Renewable Energy Law No. 5346 to support investors in renewable energy sources in 2005. The first feed-in tariff support mechanism was introduced by the Renewable Energy Law No.5346 in Turkey, yet the first FIT arrangement did not create any stimulation on solar energy investments. The FIT offered 5-5.5 eurocent/kWh payment amount for ten years, and it presented the same payment amount for all types of renewable energy plants. However, 55.5 eurocent $/ \mathrm{kWh}$ payment amount was not attractive for the emerging renewable energy market in Turkey. In 2010, the Renewable Energy Law No. 5346 was amended by Law No. 6094 - Amendment Law. In accordance with the amendment, different FIT payment amounts began to be applied for electricity from various renewable energy sources, but the 
authorities did not change contract duration. Also, the officials added new incentives in order to support domestic equipment.

Moreover, the solar energy market is supported by the Electricity Market License Regulation, the Renewable Energy Law, and its amendments. According to the Electricity Market License Regulation, Turkish Government implements the following incentives (Gozen, 2014; Simsek \& Simsek, 2013; Topkaya, 2012; Tükenmez \& Demireli, 2012): 1) Reduced License Fee: According to Electricity Market License Law, for investments in renewable energy sources fields, an entrepreneur pays only $10 \%$ of the total license fee, and investors are exempted from an annual license fee for the first eight years, 2) System Connection Priority: Connection priority has to be given to facilities based on renewable energy sources instead of non-renewable resources, 3) Purchase Obligation: All agents in retail electricity sale are required to buy electricity generated from renewable energy sources up to $40 \%$ of their annual electricity amounts, 4) Exemption from licensing and establishing company: Generation facilities based on renewable energy sources with a capacity of at most $1 \mathrm{MW}$ are exempted from licensing and establishing legal assets.

Table: 1

FIT Payment Amount with respect to Renewable Energy Type

\begin{tabular}{|c|c|c|c|}
\hline $\begin{array}{c}\text { Renewable Energy } \\
\text { Type }\end{array}$ & $\begin{array}{c}\text { FIT Payment Amount } \\
\text { (USD cent/kWh) }\end{array}$ & $\begin{array}{c}\text { Total Supplement Amount for FIT from Usage of Domestic } \\
\text { Equipment (USD cent/ kWh) }\end{array}$ & $\begin{array}{c}\text { Total Support Amount for FIT } \\
\text { (USD cent/kWh) }\end{array}$ \\
\hline Hydro & 7.3 & 2.3 & 9.6 \\
\hline Wind & 7.3 & 3.7 & 11.0 \\
\hline Geothermal & 10.5 & 2.7 & 13.2 \\
\hline Biomass & 13.3 & 5.6 & 18.9 \\
\hline Solar-PV & 13.3 & 6.7 & 20.0 \\
\hline Solar-Concentrated & 13.3 & 9.2 & 22.5 \\
\hline
\end{tabular}

Source: The additional document of Law No. 6094-Amendment Law.

Photovoltaic investments in Turkey are divided into mainly two types, unlicensed or licensed investments. Electricity produced from licensed investments can be sold in the market for forty-nine years in the energy market, but electricity produced from unlicensed investments can be sold only ten years in the scope of FIT mechanism. Moreover, firms install only $1 \mathrm{MW}$ solar power plants in unlicensed investments, but a licensed investment can be larger than $1 \mathrm{MW}$. In licensed investments, firms pay license fees for these privileges. While the licensed PV installed capacity has been $22.9 \mathrm{MW}$, the installed capacity of unlicensed PV investment has been 4,680.0 MW, and its share in total unlicensed capacity was $5.4 \%$ by the end of May 2018. ${ }^{2}$ This ratio clearly indicates that the current FIT design in Turkey does not encourage investors; hence a new FIT design is crucial to increase the PV investments. 
The rest of the article is organized as follows. The choice experiment and survey design are explained in Section 2 as the methodology. The estimated models and results are presented in Section 3, followed by discussion and conclusion in Section 4.

\section{The Methodology}

\subsection{Choice Experiment and Random Utility Model}

In this research, a survey was designed on the basis of choice experiment (CE) to find out preferences and marginal willingness to pay of investors. Choice experiment is one of the stated preference techniques which are frequently used for non-market valuation. The value of goods or services is determined by characteristics and levels in a CE study. In the $\mathrm{CE}$, the use of price as an attribute provides a multi-dimensional evaluation in cost-benefit analysis (Holmes et al., 2003). In the choice experiment, the consumer is offered a certain number of profiles and is asked to choose one of them. The consumer tries to choose an option amongst these alternatives, which gives the most utility to the consumer. Choice experiment is done on the basis of random utility maximization (RUM), and these variations can be clarified with a random element in the consumer's utility function (Adamowicz et al., 1998). RUM consists of two components, namely systematic $\left(V_{i}\right)$ and random $\left(\varepsilon_{i}\right)$ components. The person $k$ can prefer the alternative $i$, then the utility of person $k$ could be written as:

$$
U_{k i}=V_{k i}+\varepsilon_{k i}
$$

The presence of the random component allows for the estimation of consumers' behavior, and RUM offers the theoretical framework for the empirical study of consumer choices on alternatives. In this context, we express the probability of choosing the alternative $\mathrm{i}$ from alternative sets, say $\mathrm{C}$, that a consumer will encounter:

$$
P_{k i}=\operatorname{Pr}\left[U_{k i}>U_{k j}\right]=\operatorname{Pr}\left[\left(V_{k i}+\varepsilon_{k i}\right)>\left(V_{k j}+\varepsilon_{k j}\right)\right]
$$

Assuming that the error terms are Gumbel-distributed with scale parameter $\mu$, the choice probability is shown as (McFadden, 1974):

$$
P_{k i}=\exp \left(\mu v_{k i}\right) / \sum_{j \in C} \exp \left(\mu v_{k j}\right)
$$

This model is the conditional logit model. The scale parameter $\mu$ is standardized to one. The parameters are estimated with the log-likelihood function shown in (4) by using the maximum likelihood method.

$$
\ln L=\sum_{k} \sum_{i} \phi_{k i} \ln P_{k i}
$$

When the value of $\phi_{k i}$ is 1 , the person $k$ chooses the alternative $i$ and 0 otherwise. 
The marginal willingness to pay (MWTP) for the attribute is derived as the ratio of the estimated coefficients of the attributes, if $V$ is linear. The MWTP for one-unit increment of the attribute $m$ is calculated as follows:

$$
M W T P_{m}=d_{p} / d_{m}=-\frac{\partial V / \partial m}{\partial V / \partial p}=-\beta_{m} / \beta_{p}
$$

\subsection{Survey Design}

The questionnaire consists of four parts. In the first part, the respondents are asked to make assessments on the solar energy market using 1-5 scale (1- Definitely Disagree, 2Disagree, 3- Neutral, 4- Agree, 5- Definitely Agree). Firm type (Engineering, Project, Construction (EPC) firm or Solar Energy Investors), investment plans of firms, and employee's position in the firm, and her/his experience year in both current firm and sector are also revealed in this section. The second part includes CE questions. In this section, the respondents are expected to choose one of three alternatives -two hypothetical alternatives and a status quo option- in each CE. These questions are attempted to measure the MWTP of several attributes of unlicensed and licensed PV investments. The attributes and levels for CE questions are shown in Table 2. Five attributes are used for unlicensed PV investments -FIT contract period, FIT type, Payment amount per kWh, Tax for imported PV panel, and Cost per MW. Seven attributes are used for licensed PV investments - FIT contract period, FIT type, Payment amount per kWh, Tax for imported PV panel, Promotion for domestic equipment, License fee, and Cost per MW.

Table: 2

Attributes and Levels

\begin{tabular}{|c|c|}
\hline Attributes & Levels \\
\hline FIT contract period & 10-year*, 12-year, 15-year \\
\hline FIT type & Fixed*, Front-end-loaded, Inflation adjusted \\
\hline Payment amount per kWh & $\$ 0.0891, \$ 0.1291, \$ 0.133^{*}$ \\
\hline Tax for Imported PV panel & Yes* $\$ 475,000$ extra cost per MW), No \\
\hline Promotion for domestic equipment & Yes*, No \\
\hline License Fee & Yes* $(\$ 500,000$ extra cost), No \\
\hline Cost per MW & $\$ 850,000^{*}, \$ 1,000,000, \$ 1,150,000, \$ 1,300,000, \$ 1,450,000, \$ 1,600,000$ \\
\hline
\end{tabular}

* indicates status quo.

We use three levels for contract duration: Currently, 10-year is used as FIT Contract period by the ministry; hence we set 10-year as status-quo. 12-year and 15-year might increase investments and competition in the industry. We prefer to use fixed, front-end loaded, and inflation-adjusted FIT types. These three models are more suitable for developing solar energy markets. The fixed price model is the status quo. We researched FIT implementations of other countries, and we realized that they apply price discrimination according to the scale of investments. However, Turkey uses one type of price model for all PV investments. \$ 0.133 payment amount per $\mathrm{kWh}$ is used in the Turkish FIT program. The authorities think that this amount is high, and it is likely to fall in the future. Therefore, we prefer two levels $-\$ 0.0891, \$ 0.1291$, that are smaller than status-quo in order to see the willingness to accept of respondents. The government has been implementing a taxing policy for imported panels since 2016, and many firms complain about this practice. In order to 
show its negative effect on investments, we use tax for the imported panel as an attribute. Promotions for domestic equipment and license fee are only used for licensed investments because the government offers more promotions for licensed investments, and the license fee is paid only for licensed investments. We choose Cost per MW as price. We calculate the value of other attributes and levels based on the price attribute. $\$ 850,000$ is status-quo. Because the cost is increasing with respect to the equipment used, other levels have been determined by views of people working in solar energy firms.

According to full factorial design, we get $324(3 * 3 * 3 * 2 * 6)$ profile cards for unlicensed investments and $1296(3 * 3 * 3 * 2 * 2 * 2 * 6)$ profile cards for licensed investments. However, it was impossible to use all profiles; hence we use fractional factorial design, and we got 49 profiles for unlicensed investments and 52 profile cards for licensed investments with fractional factorial design by using SPSS 23 . All combinations were randomly selected. We added the status quo option to all choice sets. Each respondent was asked to answer ten questions, five for unlicensed investments five for licensed investments, and we created seven different versions of the survey with respect to $\mathrm{CE}$ questions. In the third part, policy options are presented to the participants in order to identify the desired or undesired policy implementations. The last part focuses on the socio-demographic characteristics of the respondents, such as age, gender, educational background.

\subsection{Descriptive Statistics}

Once the initial version of the survey was completed in March 2017, focus group studies and pre-test were conducted in April 2017. Data collection was finalized at the end of June 2017. Forty-four employees were interviewed from 33 solar energy firms in 8 cities (Ankara, Antakya, Denizli, Eskişehir, İstanbul, İzmir, Kayseri, Konya) of Turkey. Considering risk perception, cost-benefit based approach; we mainly conducted the survey on business executives and people working in the sales department. All the interviews are conducted face-to-face. Under the assumption that EPC firms or solar power plant investors may be more sensitive to the cost of solar energy investment, the firms to be interviewed were selected among these types of companies. Before the survey was conducted, 90 EPC firms and solar power plant investors had been determined in Turkey. The 33 companies interviewed represent approximately $37 \%$ of the solar energy market.

Descriptive statistics on the basic demographic characteristics of the respondents are summarized in Table 3. Thirty-six percent of the respondents are working in micro-scale, $59 \%$ in small scale, and 5\% in medium-scale firms. We do not have any participant working from large scale companies. According to descriptive statistics, 37 (84 percent) of the respondents are male, while just 7 of them are female. Ninety-one percent of the respondents have college degrees or higher. The average age of respondents was about 34, and 45.5 percent of data was constituted by 30-39 age group. Another detail is that 39 of the 44 respondents are engineers. 


\section{Table: 3}

\section{Descriptive Statistics for Socio-Demographic Characteristics}

\begin{tabular}{|c|c|c|c|}
\hline & & Sample (Person) & Share \\
\hline \multirow{3}{*}{ Firm scale* } & Micro Scale (1-9 employees) & 16 & $36 \%$ \\
& Small scale (10-49 employees) & $59 \%$ \\
& Medium scale (50-249 employees) & 26 & $5 \%$ \\
\hline \multirow{2}{*}{ Sex } & Large scale (+250 employees) & - & - \\
& Female & 7 & $16 \%$ \\
Education & Male & 4 & $84 \%$ \\
& College/ University-2 years & 25 & $9 \%$ \\
& College/ University-4 years & 15 & $57 \%$ \\
\hline \multirow{2}{*}{ Age } & Postgraduate & 15 & $34 \%$ \\
& $20-29$ & 20 & $34.1 \%$ \\
& $30-39$ & 5 & $45.45 \%$ \\
\hline \multirow{2}{*}{ Occupation } & $40-49$ & 33.97 & $9.09 \%$ \\
& $50-59$ & 39 & $11.36 \%$ \\
\hline
\end{tabular}

* According to Turkish Statistic Institute, the firm of 1-9 employees is micro-scale, 10-49 is small scale, 50-249 is medium scale, and +250 is large scale.

Afterward, six suggestions were presented that companies could express their plans for the next five years. The respondents evaluated by using from 1 to 5 scale, 1 implying "I strongly disagree" and 5 implying "I strongly agree." Answers to two of the questions were significant. One of them is that "We will focus on investments in rooftop PV systems over the next 5 years". Eighty-four percent of the participants state that they agree or strongly agree with suggestion-1 for the firms. Another suggestion is that "We will provide more services in the field of maintenance over the next 5 years". Seventy percent of the respondents stated that I agree, or I strongly agree with the suggestion- 2 for the firms. Following suggestions for firms' plans, 11 suggestions for the sector were presented. The respondents rated them on 1 to 5 scale. Answers to two suggestions displayed valuable outcomes. Ninety-three percent of respondents did not agree with suggestion- 1 for the solar energy sector, while $72.5 \%$ of the respondents agree or strongly agree with suggestion-2 for the solar energy sector (Table 4).

\section{Table: 4}

\section{Suggestions for the Firms and Solar Energy Sector}

\begin{tabular}{|c|c|c|c|c|}
\hline & $\begin{array}{l}\text { Suggestion- } 1 \text { for the Firms: } \\
\text { We will focus on investments in } \\
\text { rooftop PV systems over the next } \\
5 \text { years. }\end{array}$ & $\begin{array}{l}\text { Suggestion- } 2 \text { for the Firms: } \\
\text { We will provide more services in the } \\
\text { field of maintenance over the next } 5 \\
\text { years. }\end{array}$ & $\begin{array}{l}\text { Suggestion-1 for Solar Energy } \\
\text { Sector: } \\
\text { Bureaucratic procedures do not } \\
\text { cause obstacles for PV } \\
\text { investments. }\end{array}$ & $\begin{array}{c}\text { Suggestion-2 for } \\
\text { Solar Energy Sector: } \\
\text { License fees are very } \\
\text { high. }\end{array}$ \\
\hline $\begin{array}{l}\text { 1- I strongly } \\
\text { disagree }\end{array}$ & $2 \%$ & $7 \%$ & $61 \%$ & $4.5 \%$ \\
\hline 2- I disagree & $7 \%$ & $11.3 \%$ & $32 \%$ & - \\
\hline 3- Neutral & $7 \%$ & $11.3 \%$ & - & $23 \%$ \\
\hline 4- I agree & $29.5 \%$ & $27.2 \%$ & $7 \%$ & $43 \%$ \\
\hline $\begin{array}{c}\text { 5- I strongly } \\
\text { agree }\end{array}$ & $54.5 \%$ & $43.1 \%$ & - & $29.5 \%$ \\
\hline
\end{tabular}

3 Results with agree or strongly agree $>68$ percent, disagree or strongly disagree $>68$ percent or neutral $>68$ percent were selected throughout the whole section. 
The respondents were asked to evaluate seven policy recommendations, apart from suggestions related to their companies and the market. These recommendations were asked to be evaluated between 1-5 scale; 1 implying "Certainly reduces investments" and 5 implying "Certainly increases investments." Three recommendations took the highest rates. One of them presented this request for amendment: "Reduction of the tax rate for the imported panel." Ninety-three percent of the respondents stated that when the tax rate is declined, the investment would increase. The other policy recommendation is that "FIT payment should be made in Turkish Lira." Twenty-one percent of respondents claimed that this implementation would certainly reduce investments, $54 \%$ of them thought that it would reduce investments, and $18 \%$ is neutral. Despite the neutral answers, the votes for "certainly reduces investments" and "reduces investments" accounted for $75.5 \%$, and this ratio is the clearest indication that the market agents find the Turkish Lira less reliable. Lastly, the suggestion of "The obligation of establishing PV systems on the roofs of new houses" was evaluated fairly positively by the participants. $93.5 \%$ of them picked options, which are "increases investments" or "certainly increases investments" for this recommendation.

Table: 5

\section{Policy Recommendations for the Solar Energy Market}

\begin{tabular}{|c|c|c|c|}
\hline & $\begin{array}{c}\text { Recommendation:1 } \\
\text { Reduction of the tax rate for the } \\
\text { imported panel. }\end{array}$ & $\begin{array}{c}\text { Recommendation:2 } \\
\text { FIT payment should be made in } \\
\text { Turkish Lira. }\end{array}$ & $\begin{array}{c}\text { Recommendation:3 } \\
\text { The obligation of establishing PV systems on } \\
\text { the roofs of new houses. }\end{array}$ \\
\hline $\begin{array}{c}\text { 1- Certainly reduces } \\
\text { investments }\end{array}$ & - & $21.0 \%$ & - \\
\hline 2- Reduces investments & - & $54.5 \%$ & $2.0 \%$ \\
\hline 3- Neutral & $7.0 \%$ & $18.0 \%$ & $4.5 \%$ \\
\hline $\begin{array}{c}\text { 4- Increases } \\
\text { investments }\end{array}$ & $59.0 \%$ & $4.5 \%$ & $48.0 \%$ \\
\hline $\begin{array}{c}\text { 5- Certainly increases } \\
\text { investments }\end{array}$ & $34.0 \%$ & $2.0 \%$ & $45.5 \%$ \\
\hline
\end{tabular}

\section{Models and Results}

\subsection{Models}

The following five models have been examined in this study to reveal the respondents' MWTP for PV investments. Table 6 contains definitions of the variables used in the models. Model 1 is for unlicensed PV investments, and Model 2 is for licensed PV investments. These are simple linear models.

$$
\begin{aligned}
& \boldsymbol{V}=\beta_{1} \mathrm{COST}+\beta_{2} 12 \mathrm{YEAR}+\beta_{3} 15 \mathrm{YEAR}+\beta_{4} \mathrm{FRONTEND}+\beta_{5} \mathrm{INFLATION}+\beta_{6}(\$ 0.0891 \text { perkwh })+ \\
& \beta 7(\$ 0.1291 \text { perkwh })+\beta_{8} \mathrm{TAX}
\end{aligned}
$$

In Model 1, the tax for the imported panel is the dummy variable. 12 years, 15 years, front-end loaded FIT type, inflation-adjusted FIT type, \$ 0.0891 per $\mathrm{kWh}$ payment amount, $\$ 0.1291$ per $\mathrm{kWh}$ payment amount were used as factors. While we expected the signs of coefficients of 12YEAR and 15YEAR to be positive, we expected the signs of coefficients of COST, \$0.0891perkwh, TAX, and LICENSEFEE to be negative in all models.

$\boldsymbol{V}=\beta_{1} \mathrm{COST}+\beta_{2} 12 \mathrm{YEAR}+\beta_{3} 15 \mathrm{YEAR}+\beta_{4} \mathrm{FRONTEND}+\beta_{5}$ INFLATION $+\beta_{6}(\$ 0,0891$ perkwh $)+$ $\beta 7(\$ 0.1291$ perkwh $)+\beta 8$ TAX $+\beta{ }_{9}$ PROMOTION $+\beta_{10}$ LICENSEFEE

(Model 2) 
In addition to the variables used in Model 1, promotion for domestic equipment and license fee were used as the dummy variables in Model 2. We also calculate the effects of individuals' characteristics on preferences for both investment types. However, the crossterm results for unlicensed investments were not significant. In the licensed investments, only the working years in the sector as an individual characteristic is statistically significant on certain variables $(\$ 0.1291$ per $\mathrm{kWh}$ payment amount, front-end loaded FIT type, license fee).

\section{Table: 6 \\ Variable Descriptions}

\begin{tabular}{|l|l|}
\hline Variable & Definition \\
\hline COST & This variable implies the cost of 1 MW solar PV investment in all models. \\
\hline 12YEAR & This variable implies 12-year contract duration for FIT program in all models. \\
\hline 15YEAR & This variable implies 15-year contract duration for FIT program in all models. \\
\hline FRONT-END & This variable implies front-end loaded FIT type in all models. \\
\hline INFLATION & This variable implies inflation adjustment FIT type in all models. \\
\hline \$0.0891perkwh & This variable implies \$ 0.0891 payment amount per kWh in all models. \\
\hline \$0.1291perkwh & This variable implies \$ 0.1291 payment amount per kWh in all models. \\
\hline TAX & This variable implies the tax policy for the imported panel in all models. \\
\hline PROMOTION & $\begin{array}{l}\text { This variable refers to promotions offered by the government for licensed investments in model 2, model 3, } \\
\text { model 4, and model 5. }\end{array}$ \\
\hline LICENSEFEE & This variable refers to the license fee for licensed PV investments in model 2, model 3, model 4, and model 5. \\
\hline FRONTEND*YEARS_SECTOR & $\begin{array}{l}\text { This variable refers to the cross-terms of front-end loaded FIT type and individual characteristic of experience } \\
\text { years employed in the solar sector in model 3. }\end{array}$ \\
\hline \$0,1291perkwh*YEARS_SECTOR & $\begin{array}{l}\text { This variable refers to the cross-terms of \$ 0, 1291 payment amount per kWh and individual characteristic of } \\
\text { experience years employed in the solar sector in model 4. }\end{array}$ \\
\hline LICENSEFEE*YEARS_SECTOR & $\begin{array}{l}\text { This variable refers to the cross-terms of the license fee and individual characteristic of experience years } \\
\text { employed in the solar sector in model 5. }\end{array}$ \\
\hline
\end{tabular}

\section{$\boldsymbol{V}=\beta_{1} \mathrm{COST}+\beta_{2} 12 \mathrm{YEAR}+\beta_{3} 15 \mathrm{YEAR}+\beta_{4} \mathrm{FRONTEND}+\beta_{5} \mathrm{INFLATION}+$ \\ $\beta_{6}(\$ 0.0891$ perkwh $)+\beta_{7}(\$ 0.1291$ perkwh $)+\beta_{8}$ TAX $+\beta_{9}$ PROMOTION $+\beta_{10}$ LICENSEFEE + $\left(\beta_{11}\right.$ FRONTEND)YEARS_SECTOR \\ (Model 3)}

$\beta_{11}$ shows the relationship between experience years employed in the solar sector and front-end loaded FIT type in the Model 3. We expected $\beta_{11}$ to be positive, because many respondents are familiar with front-end loaded FIT payment type, and they usually found this FIT type positive.

$$
\begin{aligned}
& \boldsymbol{V}=\beta_{1} \text { COST }+\beta_{2} 12 \text { YEAR }+\beta_{3} 15 \text { YEAR }+\beta_{4} \text { FRONTEND }+\beta_{5} \text { INFLATION }+ \\
& \beta_{6}(0.0891 \text { perkwh })+\beta_{7}(0.1291 \text { perkwh })+\beta_{8} \text { TAX }+\beta_{9} \text { PROMOTION }+\beta_{10} \text { LICENSEFEE }+ \\
& \left(\beta_{12} \$ 0.1291 \text { perkwh }\right) \text { YEARS_SECTOR } \\
& \text { (Model 4) }
\end{aligned}
$$

Similarly, $\beta_{12}$ demonstrates a link between experience years employed in the solar sector and $\$ 0.1291$ per $\mathrm{kWh}$ payment amount in Model 4. We expected $\beta_{12}$ to be positive.

$$
\begin{aligned}
& \boldsymbol{V}=\beta_{1} \text { COST }+\beta_{2} 12 \text { YEAR }+\beta_{3} 15 \text { YEAR }+\beta_{4} \text { FRONTEND }+\beta_{5} \text { INFLATION }+ \\
& \beta_{6}(\$ 0.0891 \text { perkwh })+\beta 7(\$ 0.1291 \text { perkwh })+\beta_{8} \text { TAX }+\beta_{9} \text { PROMOTION }+\beta_{10} \text { LICENSEFEE }+ \\
& \left(\beta_{13} \text { LICENSEFEE }\right) \text { YEARS_SECTOR } \\
& \text { (Model 5) }
\end{aligned}
$$

Model 5 includes cross terms of the individual characteristic of experience years employed in the solar sector and license fee. $\beta_{13}$ demonstrates a link between experience years employed in the solar sector and license fee, and we expected $\beta_{13}$ to be negative. We 
Kural, D. \& S. Ara (2020), "An Analysis of the Optimal Design of Feed-in Tariff

Policy for Photovoltaic Investments in Turkey”, Sosyoekonomi, Vol. 28(46), 425-444.

can calculate the effect of individual characteristics on the MWTP for $1 \mathrm{MW}$ licensed PV investments in Model 3, Model 4, and Model 5. The coefficients of variables and price allow us to calculate the MWTP for $1 \mathrm{MW}$ unlicensed investments.

\subsection{Results}

Table 7 shows mixed logit model results obtained by using NLOGIT 4.0 software. The estimated coefficients and standard errors are presented in Table 7. The sign of Cost per MW is negative, and it is statistically significant at $1 \%$ level in all models, as expected. \$ 0.0891 payment amount per $\mathrm{kWh}$ has a negative sign. It is statistically significant. Today, the government offers $\$ 0.133$ payment amount per $\mathrm{kWh}$, and reducing the payment amount means that decreasing investment attractiveness and extending the return of the investment (ROI). Tax for imported panel has a negative sign and is statistically significant at the $1 \%$ level. In general, PV panels are imported from China, Korea, and Thailand. The number of factories producing PV panels is pretty small in Turkey, and the efficiency of the local panel is low. Many firms prefer to import panel, hence tax on imported panel decrease attractiveness of investments. It is an undesirable policy in general. While Cost per MW, \$ 0.0891 payment amount per $\mathrm{kWh}$, and tax for the imported panel are negative and statistically significant in every model, the sign of 15 -year contract duration is positive and statistically significant at the $1 \%$ level in all models, as expected. Today, FIT implemented in Turkey offers 10-year contract period for firms. Many firms claim that this period is insufficient and causes risk aversion. As market agents want to prolong the contract period, the WTP for this is rather high. The results of 12 year-contract duration are significant except Model 1. As previously stated, Model 1 is for unlicensed PV investments. The government offers a few promotions for unlicensed investments and produced electricity from these types of investments has to be sold in the market with FIT program. Under these circumstances, 12-year contract does not seem adequate for investors in unlicensed investments. A large majority of participants work in micro or small-scale companies, and they cannot compete with large scale firms about bidding. Thus, the license fee has negative coefficients in all, as expected, and it is statistically significant at the $1 \%$ level except Model 5. In Model 3, the cross-terms of front end loaded payment type and sector experience (in years) are shown. $\beta_{11}$ is the coefficient for the cross term of front end loaded payment type and sector experience, and it is statistically significant at the 5\% level, and it has a positive sign. Although different payment models are not desired instead of fixed payment in Model 1, Model 2, and Model 3, individuals who have spent more years in the industry lean towards front-end loaded payment type. Investors are more familiar with the front-end loaded payment type due to the emerging solar energy market in other countries. Because of familiarity, they may lean toward it. Model 4 demonstrates the results of cross-terms between $\$ 0.1291$ payment amount per $\mathrm{kWh}$ and sector experience. $\beta_{12}$ has a positive sign because investors were expecting a decline in the amount of payments while the period the survey was conducted. According to their expectation, \$ 0.1291 payment amount per $\mathrm{kWh}$ might be acceptable, but not $\$ 0.0891$ payment amount per $\mathrm{kWh}$. Lastly, the cross term between license fee and sector experience has a negative sign, and it is statistically significant at the $1 \%$ level. This result was supported by attitudes in other models. The license fee is a big obstacle for micro and small-scale firms. 
Table: 7

Estimated Coefficients of Mixed Logit Model

\begin{tabular}{|c|c|c|c|c|c|}
\hline & Model 1 & Model 2 & Model 3 & Model 4 & Model 5 \\
\hline COST PER MW (in $10^{5}$ ) & $\begin{array}{c}-0.516^{* * * *} \\
(0.174)\end{array}$ & $\begin{array}{c}-0.452^{* * * *} \\
(0.122)\end{array}$ & $\begin{array}{c}-0.549^{* * * *} \\
(0.168)\end{array}$ & $\begin{array}{c}-0.422^{* * * *} \\
(0.125)\end{array}$ & $\begin{array}{c}-0.410^{* * * *} \\
(0.118)\end{array}$ \\
\hline 12 YEARS & $0.478(0.625)$ & $\begin{array}{c}1.502 * * * \\
(0.575)\end{array}$ & $\begin{array}{l}1.770 * * \\
(0.699)\end{array}$ & $\begin{array}{c}1.591 * * * \\
(0.597)\end{array}$ & $\begin{array}{l}1.360^{* *} \\
(0.539)\end{array}$ \\
\hline 15 YEARS & $\begin{array}{c}2.623 * * * \\
(1.023)\end{array}$ & $\begin{array}{c}2.323 * * * \\
(0.718)\end{array}$ & $\begin{array}{c}2.346^{* * * *} \\
(0.823)\end{array}$ & $\begin{array}{c}2.546 * * * \\
(0.756)\end{array}$ & $\begin{array}{c}2.200 * * * \\
(0.647)\end{array}$ \\
\hline FRONT END LOADED FIT TYPE & $-0.174(0.643)$ & $\begin{array}{c}-1.182^{* * *} \\
(0.482) \\
\end{array}$ & $4.983(5.500)$ & $\begin{array}{c}-1.264 * * \\
(0.529)\end{array}$ & $\begin{array}{c}-1.088 * * \\
(0.444)\end{array}$ \\
\hline INFLATION ANDJUSTED FIT TYPE & $0.980(0.867)$ & $-0.230(0.519)$ & $-0.404(0.658)$ & $-0.142(0.515)$ & $-0.345(0.451)$ \\
\hline 0.0891 PER KWH PAYMENT & $\begin{array}{c}-4.747^{* * *} \\
(1.494)\end{array}$ & $\begin{array}{c}-3.475^{* * * *} \\
(1.178)\end{array}$ & $\begin{array}{c}-4.068 * * * \\
(1.438)\end{array}$ & $\begin{array}{c}-3.457^{* * * *} \\
(1.261)\end{array}$ & $\begin{array}{c}-3.058^{* * *} \\
(1.138)\end{array}$ \\
\hline 0.1291 PER KWH PAYMENT & $-1.065(0.606)$ & $-0.479(0.436)$ & $-0.392(0.480)$ & $3.982(3.390)$ & $-0.501(0.404)$ \\
\hline TAX FOR IMPORTED PANEL & $\begin{array}{c}-2.987 * * * \\
(0.982)\end{array}$ & $\begin{array}{c}-1.915^{* * * *} \\
(0.588)\end{array}$ & $\begin{array}{c}-2.348 * * * \\
(0.766)\end{array}$ & $\begin{array}{c}-1.917 * * * \\
(0.596)\end{array}$ & $\begin{array}{c}-1.786 * * * \\
(0.573)\end{array}$ \\
\hline PROMOTION FOR DOMESTIC EQUIPMENT & & $0.969 *(0.572)$ & $1.161(0.725)$ & $1.109 *(0.598)$ & $0.715(0.493)$ \\
\hline LICENSE FEE & & $\begin{array}{c}-2.611 * * * \\
(0.696)\end{array}$ & $\begin{array}{c}-2.971 * * * \\
(0.845)\end{array}$ & $\begin{array}{c}-2.555^{* * * *} \\
(0.739)\end{array}$ & $-2.160(3.482)$ \\
\hline $\begin{array}{c}\text { FRONT END LOADED FIT } \\
\text { TYPE_SECTOREXPERIENCEYEARS }\end{array}$ & & & $\begin{array}{c}0.482 * * \\
(0.219) \\
\end{array}$ & & \\
\hline $\begin{array}{l}0.1291 \text { PER KWH PAYMENT } \\
\text { SECTOREXPERIENCEYEARS }\end{array}$ & & & & $\begin{array}{l}0.323 * * \\
(0.147) \\
\end{array}$ & \\
\hline LICENSEFEE_SECTOREXPERIENCEYEARS & & & & & $\begin{array}{c}-0.421 * * * \\
(0.151) \\
\end{array}$ \\
\hline $\mathrm{N}$ & 220 & 220 & 220 & 220 & 220 \\
\hline $\log \mathrm{L}$ & -158.145 & -153.836 & -147.683 & -149.951 & -148.507 \\
\hline
\end{tabular}

***, **, and * indicate that the parameter is significant at $1 \%, 5 \%$, and $10 \%$ level, respectively. Figures in parentheses are standard errors.

The MWTP results are shown in Table 8 . As mentioned before, the MWTP results were obtained by using coefficients in Table 7. MWTP formula is as follows:

$$
\text { MWTP }=-\frac{\beta_{\text {Characteristic }}}{\beta_{\text {Price }}}
$$

Positive MWTP implies that the respondents have a willingness to pay a positive amount for one unit good or service. The negative result shows that the attribute is unattractive for investors. When Table 8 is well examined, it will be clearly seen that the highest MWTP belongs to 15-year contract duration in all. \$ 0.0891 payment amount per $\mathrm{kWh}$ and tax for imported panel decrease the attractiveness of investments.

As in Table 7, Model 1 results are for unlicensed PV investments, while others are for licensed PV investments in Table 8. In Model 1, 15-year contract duration has \$ 508,000 MWTP. It means that the FIT scenario with 15-year contract duration brings $\$ 508,000$ MWTP more, compared to 10-year contract duration. This means that the investors are willing to invest $\$ 508,000$ more if the contract is 15 -year instead of 10-year. Even though 15-year contract duration has a higher rate in all models, the highest MWTP belongs to Model 1 among them. It shows investors' concerns for unlicensed PV investments because electricity produced from unlicensed plants can be sold just for 10-years in the market. If FIT contract period prolongs, the firms will be more willing to invest in PV systems.

The \$ 0.0891 payment amount per kWh has negative MWTP in all. Currently, the government offers $\$ 0.133$ payment amount per $\mathrm{kWh}$. Decreasing the payment amount 
means decreasing the attractiveness of investments; hence the participants have found negative this option. To be more precise, considering Model 1, the scenario with $\$ 0.0891$ payment amount per $\mathrm{kWh}$ will decrease the attractiveness of investments for the respondents, causing a drop of $\$ 919,900$ in investments compared to $\$ 0.133$ payment amount per kWh for $1 \mathrm{MW}$ unlicensed investments. Tax for imported panel has negative MWTP as in \$ 0.0891 payment amount per $\mathrm{kWh}$ in all models. It means that this feature decreases the attractiveness of investments.

In Model 2 (licensed investments), WTP of 15-year is greater than the one for Model 1 (unlicensed investment). In addition, licensed investment scenarios with 12 -year period have three times more WTP than Model 1. Since the licensed investment has a longer sales period, 12-year scenario is more acceptable for licensed investments. The license fee, which is a dummy variable, has negative WTP in all licensed models. The government distributed $600 \mathrm{MW}$ capacities for the first time for licensed investments by using tenders-bidding in 2015. After the tenders, only big-scale firms obtained licenses. This implementation threatens the existence of micro or small-scale firms that make up the majority of the market. The negative attitude in MWTP results for license fee is normal because most of the respondents in the sample work in micro or small-scale firms. Some of the respondents have stated that they did not find this method wrong; they think that large-scale investments can be financed by firms that are financially stronger. If a firm cannot pay the license fee, it probably will not be able to complete a major investment.

Table: 8

$$
\text { MWTP Results [ MWTPX } \left.=\left(-\frac{\beta_{X}}{\beta_{\text {Cost per } M W}}\right)\left(\mathbf{1 0}^{5}\right)\right]
$$

\begin{tabular}{|c|c|c|c|c|c|}
\hline & $\begin{array}{c}\text { Model } 1 \\
(\$)\end{array}$ & Model $2(\$)$ & Model $3(\$)$ & Model $4(\$)$ & Model $5(\$)$ \\
\hline 12 YEARS & 92,600 & $\mathbf{3 3 2 , 3 0 0}$ & $\mathbf{3 2 2 , 4 0 0}$ & $\mathbf{3 7 7 , 0 0 0}$ & $\mathbf{3 3 1 , 7 0 0}$ \\
\hline 15 YEARS & $\mathbf{5 0 8 , 0 0 0}$ & $\mathbf{5 1 3 , 9 0 0}$ & $\mathbf{4 2 7 , 3 0 0}$ & $\mathbf{6 0 3 , 3 0 0}$ & $\mathbf{5 3 6 , 5 0 0}$ \\
\hline FRONT END LOADED FIT TYPE & $-33,700$ & $\mathbf{- 2 6 1 , 5 0 0}$ & 907,600 & $\mathbf{- 2 9 9 , 5 0 0}$ & $\mathbf{- 2 6 5 , 3 0 0}$ \\
\hline INFLTION ANDJUSTED FIT TYP & 189,000 & $-50,800$ & $-73,500$ & $-33,600$ & $-84,100$ \\
\hline 0.0891 PER KWH PAYMENT & $\mathbf{- 9 1 9 , 9 0 0}$ & $\mathbf{- 7 6 8 , 8 0 0}$ & $\mathbf{- 7 4 0 , 9 0 0}$ & $\mathbf{- 8 1 9 , 1 0 0}$ & $-\mathbf{7 4 5 , 8 0 0}$ \\
\hline 0.1291 PER KWH PAYMENT & $-206,300$ & $-105,900$ & $-71,400$ & 943,600 & $-122,100$ \\
\hline TAX FOR IMPORTED PANEL & $\mathbf{- 5 7 8 , 8 0 0}$ & $\mathbf{- 4 2 3 , 6 0 0}$ & $\mathbf{- 4 2 7 , 6 0 0}$ & $\mathbf{- 4 5 4 , 2 0 0}$ & $\mathbf{- 4 3 5 , 6 0 0}$ \\
\hline PROMOTION FOR DOMESTIC EQUIPMENT & & $\mathbf{2 1 4 , 3 0 0}$ & 211,400 & $\mathbf{2 6 2 , 7 0 0}$ & 174,300 \\
\hline LICENSE FEE & & $\mathbf{- 5 7 7 , 0 0 0}$ & $\mathbf{- 5 4 1 , 1 0 0}$ & $\mathbf{- 6 0 5 , 4 0 0}$ & $-526,800$ \\
\hline FRONTENDLOADEDFITTYPE_SECTOREXPERIENCEYEARS & & & $\mathbf{8 , 7 7 0}$ & & \\
\hline 0.1291 PER KWH PAYMENT_SECTOREXPERIENCEYEARS & & & & $\mathbf{7 6 , 5 0 0}$ & \\
\hline LICENSE FEE_SECTOREXPERIENCEYEARS & & & & & $\mathbf{- 1 0 2 , 6 0 0}$ \\
\hline
\end{tabular}

Bold numbers refer to significance.

The models with cross-terms are in Model 3, Model 4, and Model 5 in order to reveal the effects of individual characteristics on WTP. Model 3 shows the relationship between front-end-loaded FIT type and sector experience (as years). As the industry experience increases, individuals have taken a bright view of the scenario with a front-end-loaded FIT type. It brings about $\$ 8,770$ more WTP per MW for front-end-loaded FIT type compared to fixed FIT type in licensed investments. Model 4 involves the cross-terms of $\$ 0.1291$ payment amount per kWh and sector experience. While surveying, there was a rumor that the payment per $\mathrm{kWh}$ would be decreased. It is possible that due to the rumor, $\$ 0.1291$ payment amount is found to be more admissible, and it is positive. In Model 5, license fee 
and sector experience cross-terms were investigated. It has a negative WTP result, i.e., $102,600 \$$, implying that employees do not find tenders as a healthy way to improve the sector.

\section{Discussion and Conclusion}

This study attempts to reveal optimal FIT design for PV investments in Turkey by examining the preferences and attitudes of employees working in solar energy firms. Although the survey study forms the basis of this research, it is not possible to ignore the contributions of the institutions, firms, and other countries' experiences. By considering all this information, an overall assessment and some policy implementations are provided below.

The starting point of this research was that Turkey's FIT contract period is shorter than that of many other countries. We could not reach a satisfying answer to how current FIT was designed from the public sector in Turkey. However, several solar energy firms and solar energy societies claim that FIT design only is not sufficient to increase PV investments. We began to research these claims and prepared the questionnaire by using a CE approach. Findings from data endorsed the arguments about the solar energy market of Turkey. The policy analysis became solidly backed up with the evidence provided by statistical and econometric analyses.

Firstly, we can state that 10-year contract duration FIT design is the biggest obstacle for the growth of the solar industry. According to WTP results, the respondents showed the highest WTP amount for the scenario with 15-year contract period. It is clearly observed that investments will increase with a longer FIT. Authorities should not try to cover up this flaw in the FIT design by claiming a high payment amount per kWh. However, it is predicted that the increased distribution costs since the beginning of this year will decrease the attractiveness of a high amount of payment per kWh.

The second important hurdle is the implementation of a tax for the imported panel. This policy was the result of the lobbying activities of domestic panel manufacturers in 2016. However, this practice almost paralyzed the PV sector. Instead of tax policy, it is recommended that authorities seek technology and know-how to compete with foreign products. At this point, it should be noted that the government has made an effort on local panel production, not assembly production. ${ }^{4}$ If this panel factory provides know-how, it is considered that Turkey would benefit in the long term.

Another undesirable policy implementation is revealing the license fee by using bidding. In accordance with econometric results, this method engenders negative WTP. In 2015, the authorities arranged the first auction to distribute capacities for licensed 
investments. However, several firms had to retreat because they could not compete with large-scale firms' biddings. This may lead to monopoly or oligopolies. When we conducted the survey, the government held a tender for the second time. They followed the different procedures in order to overcome the threat of monopoly or oligopoly in the market. The minimum payment amount per kWh that firms would accept was asked, and companies offering the lowest amount earned capacities. This application did not cause an additional cost, but it has reduced the profitability ratio of PV investments. It cannot be said that the new technique has created a solution to the existing problem of competitiveness and balance in the market. Different ways should be found to distribute capacities; otherwise, several small-scale firms will be closed in the future.

The radical amendments (such as tax policy for the imported panel) cause a serious problem. Furthermore, the tense political atmosphere triggers extreme volatility in the exchange rate. Even if the payments under the FIT are made in US dollars, Turkey has an import-dependent production structure, and fluctuations in the exchange rate are adversely affecting the market in general. ${ }^{5}$ Given the above shortcomings, the decision-makers might lose the confidence of investors. Individuals may avoid making long-term investments, and the willingness of the private sector to invest in solar energy may decrease. It is thought that the atmosphere of instability and insecurity may deeply affect the dialogue between the public sector and the private sector negatively. Manipulations may increase, and investment decisions might be difficult to take due to the above reasons.

As the market is an emerging market, many of the above-mentioned shortcomings are expected to be overcome in time. There are many advantages as well as disadvantages of being an emerging market. For instance, the solar energy market has a young and highly dynamic structure. It is thought to be easily adaptable to innovations. Moreover, market agents often make meetings to discuss problems and necessities. They are quite open to the supports and suggestions of other organizations- NGOs, NPOs. They also continue their dialogue with officials in the public sector. In addition, Turkey has geographical advantages in solar energy. If the officials continue to provide support for solar energy, solar energy investments will contribute to the reduction of energy dependency of Turkey.

In light of the advantages and disadvantages of the market and the main findings of the study, it is possible to make some policy recommendations. Primarily, the authorities should definitely revise the FIT design. For instance, they should design FIT with regard to investment types (unlicensed, licensed investments, and rooftop PV systems). Various contract periods, payment amounts should be used for each investment type. In other words, the government should give up monotype FIT implementation for all. In any case, a longer contract period than 10-year is recommended. However, the contract duration should not be

5 Note to show fluctuation in US dollar: at the beginning of this study 1 Turkish Lira (TL) was around \$ 2.89, while surveying 1 TL fluctuated between \$ 3.48 and \$ 3.79; In July 2018, 1 TL is fluctuated between \$ 4.78 and $\$ 4.85$ and in August 2018, it was between \$ 4.92 and \$ 6.88 . 
exceeded 15 years in order to protect the dynamic and competitive market structure. Implementation-monitoring-evaluation-revising is essential for this market due to the fact that it is an emerging industry. Given that both the solar energy market is an emerging market, and the exchange rate is unstable, the fixed payment type is considered to be more appropriate for the market.

Secondly, the policymakers should make decisions by focusing on their long-term returns, and they should tackle the problems from roots, not as temporary solutions. Before amendments, the opinions of experts from all fields of the market should be taken into consideration. Last but not least, investing in rooftop PV systems is expected to be highly profitable in the long run. The government should offer various incentives to make it more attractive for households and firms. If households want to transfer the electricity generated from the rooftop photovoltaic systems to the grid, they can benefit from FIT program. Therefore, households can be sold electricity, and the government pays a certain amount of payment per kWh. However, the government cuts $20 \%$ income tax from these earnings. Longer contract period, abandonment of income tax for households, discounts, and certificates, advertisements for awareness are some policy recommendations to make PV investments more attractive.

In recent studies, the alternative policies to FIT and the post-FIT (both reduction and removal of price incentives) schemes are also discussed (Baur \& Uriona, 2018; Castaneda et al., 2020; Gornowicz \& Castro, 2020; Xin-gang \& Pei-ling \& Ying, 2020). However, the analysis of post-FIT is out of the scope of this article and is set as our future work.

Several studies on the solar energy market and renewable energy sources are available in Turkey. However, to the best of our knowledge, measuring the willingness to pay/ invest on the basis of CE and trying to determine the desired components of FIT design have not been examined in any previous study in the literature. This unique characteristic contributes to the existing literature and provides a pathway for future studies.

Finally, this study was done for the implementations, which would increase PV investment. As everyone knows, the world is facing threats of climate change and degradations of ecological balance. Unless the transition to low-carbon economies achieved, the world will not be a place to live for all living things. Turkey is expected to benefit more from renewable energy sources, in particular solar energy and PV systems. This will be the healthiest attitude for both its own economy and a livable world. 


\section{Appendix: Example CE Profiles}

Fig. 4

Example of CE Question for Unlicensed Investments

\begin{tabular}{|c|c|c|c|}
\hline Attributes & PROGRAM A & PROGRAM B & PROGRAM C \\
\hline FIT contract period & 15-Year & 10-Year & Fixed payment model \\
\hline FIT type & Inflation-adjusted payment model & Front-end-loaded payment model & \$ 0.133 \\
\hline Payment amount per kWh & $\$ 0.1231$ & NO & YES(\$ 475,000 extra cost per MW) \\
\hline Tax for Imported PV panel & NO & $\$ 850,000$ & \\
\hline Cost per MW & $\$ 1,000.000$ & & \\
\hline Choice: & & & \\
\hline
\end{tabular}

Fig. 5

Example of CE Question for Licensed Investments

\begin{tabular}{|c|c|c|c|}
\hline Attributes & PROGRAM A & PROGRAM B & PROGRAM C \\
\hline FIT contract period & 15-Year & 12-Year & 10-Year \\
\hline FIT type & Inflation-adjusted payment model & Inflation-adjusted payment model & Fixed payment model \\
\hline Payment amount per kWh & $\$ 0.1231$ & $\$ 0.133$ & $\$ 0.133$ \\
\hline Promotion for domestic equipment & NO & NO & YES \\
\hline License Fee & $\begin{array}{c}\text { YES } \\
(1,800,000 \text { TL extra cost per MW) }\end{array}$ & NO & $\begin{array}{c}\text { YES } \\
(1,800,000 \text { TL extra cost per MW) }\end{array}$ \\
\hline Tax for Imported PV panel & NO & NO & $\begin{array}{c}\text { YES } \\
(\$ 475,000 \text { extra cost per MW })\end{array}$ \\
\hline Cost per MW & $\$ 1,300,000$ & $\$ 850,000$ & $\$ 850,000$ \\
\hline Choice: & & & \\
\hline
\end{tabular}

\section{References}

Adamowicz, W. \& J. Louviere \& J. Swait (1998), "Introduction to attribute-based stated choice methods", NOAA-National Oceanic Atmospheric Administration, Washington, USA.

Baur, L. \& M. Uriona (2018), "Diffusion of photovoltaic technology in Germany: A sustainable success or an illusion driven by guaranteed feed-in tariffs?", Energy, 150, 289-298.

Benli, H. (2013), "Potential of renewable energy in electrical energy production and sustainable energy development of Turkey: Performance and policies", Renewable Energy, 50, 3346.

Bilgen, S. \& S. Keleş \& A. Kaygusuz \& A. Sarı \& K. Kaygusuz (2008), “Global warming and renewable energy sources for sustainable development: a case study in Turkey", Renewable and Sustainable Energy Reviews, 12(2), 372-396.

Campoccia, A. \& L. Dusonchet \& E. Telaretti \& G. Zizzo (2014), “An analysis of feed' in tariffs for solar PV in six representative countries of the European Union", Solar Energy, 107, 530542.

Castaneda, M. \& S. Zapata \& J. Chernic \& A.J. Aristizabal \& I. Dyner (2020), "The long-term effects of cautious feed-in tariff reductions onphotovoltaic generation in the UK residential sector", Reneweable Energy, 155, 1432-1443.

Couture, T. \& Y. Gagnon (2010), “An analysis of feed-in tariff remuneration models: Implications for renewable energy investment”, Energy Policy, 38(2), 955-965.

Couture, T.D. \& K. Cory \& C. Kreycik \& E. Williams (2010), "Policymaker's guide to feed-in tariff policy design", (No. NREL/TP--6A2-44849), National Renewable Energy Lab. (NREL), Golden, CO (United States).

Gazete, R. (2005), 10.05.2005 tarih ve 5346 sayılı Yenilenebilir Enerji Kaynaklarının Elektrik Enerjisi Üretimi Amaçlı Kullanımına İlişkin Kanun. 
Gazete, R. (2011), 6094 sayılı Yenilenebilir Enerji Kaynaklarının Elektrik Enerjisi Üretimi Amaçlı Kullanımına İliş̧kin Kanunda Değişiklik Yapılmasına Dair Kanun, Resmi Gazete (27809), 20110108-20110103.

Gornowicz, R. \& R. Castro (2020), "Optimal design and economic analysis of a PV system operating under Net Metering or Feed-In-Tariff support mechanisms: A case study in Poland", Sustainable Energy Technologies and Assessments, 42, 100863.

Gozen, M. (2014), "Renewable energy support mechanism in Turkey: Financial analysis and recommendations to policymakers", International Journal of Energy Economics and Policy, 4(2), 274.

Haas, R. \& C. Panzer \& G. Resch \& M. Ragwitz \& G. Reece \& A. Held (2011), “A historical review of promotion strategies for electricity from renewable energy sources in EU countries", Renewable and Sustainable Energy Reviews, 15(2), 1003-1034.

Holmes, T.P. \& W.L. Adamowicz \& P.A. Champ \& K.J. Boyle \& T.C. Brown (2003), A primer on non-market valuation, New York: Kluwer Academic Publishers.

Jacobs, D. \& B. Sovacool (2012), "Feed-in tariffs and other support mechanisms for solar PV promotion", Comprehensive Renewable Energy, 1, 73-109.

Klein, A. \& A. Held \& M. Ragwitz \& G. Resch \& T. Faber (2008), Evaluation of different feed-in tariff design options: Best practice paper for the International Feed-in Cooperation, Energy Economics Group \& Fraunhofer Institute Systems and Innovation Research, Germany, <www.feed-in-cooperation.org/wDefault_7/downloadfiles/research/Best_practice_Paper_3rd_edition.pdf >, 28.08.2019.

McFadden, D. (1974), “Conditional Logit Analysis of Qualitative Choice Behavior”, in: P. Zarembka (ed.), Frontiers in Econometrics, Academic Press.

Mendonca, M. \& D. Jacobs \& B.K. Sovacool (2009), Powering the green economy: The feed-in tariff handbook: Earthscan.

Serencam, H. \& U. Serencam (2013), "Toward a sustainable energy future in Turkey: An environmental perspective", Renewable and Sustainable Energy Reviews, 27, 325-333.

Simsek, H.A. \& N. Simsek (2013), "Recent incentives for renewable energy in Turkey”, Energy Policy, 63, 521-530.

Topkaya, S.O. (2012), “A discussion on recent developments in Turkey's emerging solar power market", Renewable and Sustainable Energy Reviews, 16(6), 3754-3765.

Tükenmez, M. \& E. Demireli (2012), "Renewable energy policy in Turkey with the new legal regulations", Renewable Energy, 39(1), 1-9.

Yuksel, I. \& K. Kaygusuz (2011), "Renewable energy sources for clean and sustainable energy policies in Turkey", Renewable and Sustainable Energy Reviews, 15(8), 4132-4144.

Xin-gang, Z. \& L. Pei-ling \& Z. Ying (2020), "Which policy can promote renewable energy to achieve grid parity? Feed-in tariff vs. renewable portfolio standards", Renewable Energy, $162,322-333$. 
Kural, D. \& S. Ara (2020), “An Analysis of the Optimal Design of Feed-in Tariff Policy for Photovoltaic Investments in Turkey”, Sosyoekonomi, Vol. 28(46), 425-444. 